Pasukat Sembiring, et al Counseling to the Karo Regency Tourism and Culture Office for Optimizing the Selection of Tourism Routes in Karo Regency

\title{
Counseling to the Karo Regency Tourism and Culture Office for Optimizing the Selection of Tourism Routes in Karo Regency
}

\author{
Pasukat Sembiring ${ }^{1 *}$, Rudy Sofyan ${ }^{2}$ \\ ${ }^{1}$ Department of Mathematics, Faculty Science and Mathematics, Universitas Sumatera Utara, \\ Medan, Indonesia \\ ${ }^{2}$ Department of Culture, Faculty Cultural Studies, Universitas Sumatera Utara, Medan, \\ Indonesia
}

*Email: pasukat@usu.ac.id

\begin{abstract}
Tourism is an effort by the Karo Regency Government to increase the potential of a region that is experiencing very rapid development. The development of tourism will have an influence on the life of the local community, that is, it can affect various aspects of life, be it social, economic, cultural, religious, language and also the environment. The extent of the influence of tourism development on aspects of life can be studied independently. In addition, tourism also plays a major role in expanding employment opportunities, encouraging activities of supporting industries, introducing natural and cultural beauty that is inseparable from a sense of increasing brotherhood in the national and international environment. This is because tourism itself creates multiple economic impacts, namely direct, indirect, secondary impacts, which provide opportunities for business growth and the role of local communities in the tourism sector. This research will discuss about determining the shortest route of tourist attractions in Karo Regency. The result achieved is the optimization of travel routes on tourist objects in Karo district so that the Karo Regency tourism office can provide more information regarding the location of tourist objects that will be traversed by local and foreign tourists.
\end{abstract}

Keywords: Shortest Path, Tourism Objects, Tourism, Dynamic Program

\begin{abstract}
Abstrak
Pariwisata merupakan satu usaha Pemerintah Kabupaten Karo dalam meningkatkan potensi daerah yang mengalami perkembangan sangat pesat. Perkembangan pariwisata akan memberikan pengaruh terhadap kehidupan masyarakat setempat, yakni dapat mempengaruhi berbagai aspek kehidupan, baik itu sosial, ekonomi, budaya, religi, bahasa dan juga lingkungannya. Luasnya pengaruh perkembangan pariwisata terhadap aspek kehidupan dapat dikaji secara mandiri. Disamping itu, pariwisata juga berperan besar dalam perluasan lapangan kerja, mendorong kegiatan-kegiatan industri penunjang, memperkenalkan keindahan alam dan budaya yang tak terlepas dari rasa untuk meningkatkan persaudaraan dalam lingkungan nasional dan internasional. Hal ini dikarenakan pariwisata sendiri menciptakan dampak ekonomi multiganda yaitu dampak langsung, tak langsung, ikutan, yang memberi peluang bagi tumbuhnya usaha dan peran masyarakat lokal dalam sektor kepariwisataan. Penelitian ini akan membahas tentang penentuan rute terpendek tempat wisata di Kabupaten Karo. Hasil yang dicapai adalah optimasi rute perjalanan pada objek wisata di kabupaten karo sehingga dinas pariwisata kabupaten karo dapat lebih memberikan informasi terkait lokasi objek wisata yang akan dilalui oleh turis lokal dan mancanegara.
\end{abstract}

\section{Kata Kunci: Shortest Path, Objek Wisata, Pariwisata, Program Dinamik}

\section{PENDAhuluan}

Pariwisata merupakan satu usaha Pemerintah Kabupaten Karo dalam meningkatkan potensi daerah yang mengalami perkembangan sangat pesat. Perkembangan pariwisata akan memberikan pengaruh terhadap kehidupan masyarakat setempat, yakni dapat mempengaruhi berbagai aspek kehidupan, baik itu sosial, ekonomi, budaya, religi, bahasa dan juga lingkungannya. Luasnya pengaruh 
Pasukat Sembiring, et al Counseling to the Karo Regency Tourism and Culture Office for Optimizing the Selection of Tourism Routes in Karo Regency

perkembangan pariwisata terhadap aspek kehidupan dapat dikaji secara mandiri. Disamping itu, pariwisata juga berperan besar dalam perluasan lapangan kerja, mendorong kegiatan-kegiatan industri penunjang, memperkenalkan keindahan alam dan budaya yang tak terlepas dari rasa untuk meningkatkan persaudaraan dalam lingkungan nasional dan internasional. Hal ini dikarenakan pariwisata sendiri menciptakan dampak ekonomi multiganda yaitu dampak langsung, tak langsung, ikutan, yang memberi peluang bagi tumbuhnya usaha dan peran masyarakat lokal dalam sektor kepariwisataan.

Pembangunan Infrastruktur merupakan suatu strategi dalam penyediaan sarana dan prasarana. Peran infrastruktur tidak hanya berpengaruh pada pengembangan wilayah, tetapi juga pada bidang kepariwisataan. Infrastruktur berperan sangat penting dalam mendorong kualitas wisata itu sendiri serta pada lingkungan sekitarnya. Walaupun hanya bersifat sebagai pendukung, infrastruktur memiliki posisi yang amat penting bagi keberlangsungan kegiatan masyarakat di suatu wilayah. Aktivitas yang di tampung dalam suatu ruang tidak akan berjalan dengan baik tanpa didukung oleh pelayanan infrastruktur yang memadai seperti jaringan tanah, air bersih, persampahan, listrik, sanitasi dan telekomunikasi. Beberapa hal yang dapat mendukung pelayanan infrastruktur tersebut adalah membuat beberapa pilihan paket wisata yang efektif dan dapat menjangkau semua lokasi wisata yang diinginkan wisatawan.

\section{METODE PELAKSANAAN}

Kegiatan ini akan dilaksanakan pada kurun waktu Bulan April sampai dengan Bulan September dengan memberikan pelatihan bagi Dinas Pariwisata dan Kebudayaan di Kabupaten Karo dengan tujuan agar Dinas Pariwisata dan Kebudayaan di Kabupaten Karo dapat melaksanakan optimisasi transportasi darat menggunakan program dinamik. Metodologi penelitian yang digunakan dalam penelitian ini adalah metode survei. Untuk menganalisa permasalahan penelitian, dilakukan dalam beberapa tahapan sebagai berikut:

Tahapan metode pelaksanaan kegiatan dibagi menjadi 3 bagian yakni:

1. Awal Pelaksanaan

Pada tahap ini dilakukan beberapa aktivitas antara lain

a. Pengumpulan Data

Populasi dalam penelitian ini adalah lokasi wisata di Sumatera Utara. Pengambilan data dilakukan berdasarkan jarak dan waktu tempuh perjalanan.

b. Studi Kepustakaan

Studi kepustakaan dilakukan dengan mencari referensi untuk kebutuhan teoritis tentang kegiatan pengabdian masyarakat berbasis penelitian. Studi kepustakaan berupa buku-buku, jurnal, dan internet.

c. Analisis Kebutuhan

Pada tahap ini melakukan analisis terhadap kebutuhan-kebutuhan yang dapat menunjang penerapan kegiatan. Beberapa aspek analisis kebutuhan diantaranya lokasi, perlengkapan, bahan bacaan dan peralatan penunjang.

d. Tinjauan Lokasi

e. Tim pengusul melakukan kunjungan ke lokasi kegiatan sebagai bagian dari tahap pelaksanaan sehingga tim dapat mengetahui kondisi lapangan yang akan menjadi tempat pelaksanaan kegiatan. Tinjauan lokasi dilakukan berulang kali untuk menjamin komunikasi interaktif terhadap lokasi kegiatan.

2. Pelaksanaan

Alat utama yang digunakan untuk mengumpulkan data dalam penelitian ini adalah:

a. Navigasi atau GPS, untuk menghitung jarak setiap lokasi keperluan data sekunder yang kemudian dilakukan tinjauan perjalanan ke lokasi.

b. Laptop, digunakan untuk menginput dan mengolah data yang dikumpulkan oleh surveyor, dan printer untuk mencetak berbagai instrument cetak yang diperlukan 
Pasukat Sembiring, et al Counseling to the Karo Regency Tourism and Culture Office for Optimizing the Selection of Tourism Routes in Karo Regency

3. Pasca Pelaksanaan

Kegiatan pada tahap ini antara lain adalah:
a. Penyusunan laporan kegiatan
b. Seminar di pertemuan ilmiah.
c. Publikasi di Jurnal Internasional atau prosiding internasional
d. Pembuatan laporan akhir

\section{HASIL DAN PEMBAHASAN}

Secara geografis, Kabupaten Karo terletak pada koordinat $02^{\circ} 50^{\prime}$ sampai $03^{\circ} 19^{\prime}$ Lintang utara dan $97^{\circ} 55^{\prime}$ sampai $98^{\circ} 38^{\prime}$ Bujur timur. Kabupaten ini memiliki luas wilayah $2.127,25 \mathrm{~km}^{2}$ dan berpenduduk sebanyak 415.878 jiwa. Kabupaten karo berada $1.400 \mathrm{~m}$ di atas permukaan laut hal ini menyebabkan kabupaten karo memiliki tingkat kelembapan suhu berkisar pada 160C - 170C hal tersebut mengakibatkan karo menjadi salah satu wilayah pariwisata di daerah provinsi sumatera utara.

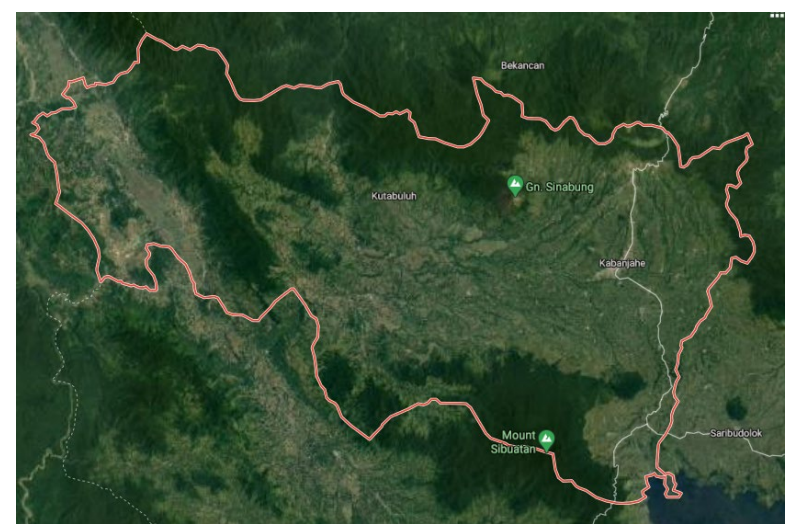

(Sumber: Google maps)

Gambar 4. 1 Peta Kabupaten Karo

Untuk menentukan optimasi model matematika terhadap penentuan rute terpendek mula-mula akan dilakukan diskritasi model menjadi 4 bagian yaitu objek wisata bagian utara, selatan, barat, dan timur dengan titik awal perjalanan di pemandian air panas lau sidebuk-debuk. Berdasarkan peta kabupaten karo maka model peta dengan mengunakan model ilustrasi graf berbobot adalah seperti pada gambar 4.2 . 
Pasukat Sembiring, et al Counseling to the Karo Regency Tourism and Culture Office for Optimizing the Selection of Tourism Routes in Karo Regency

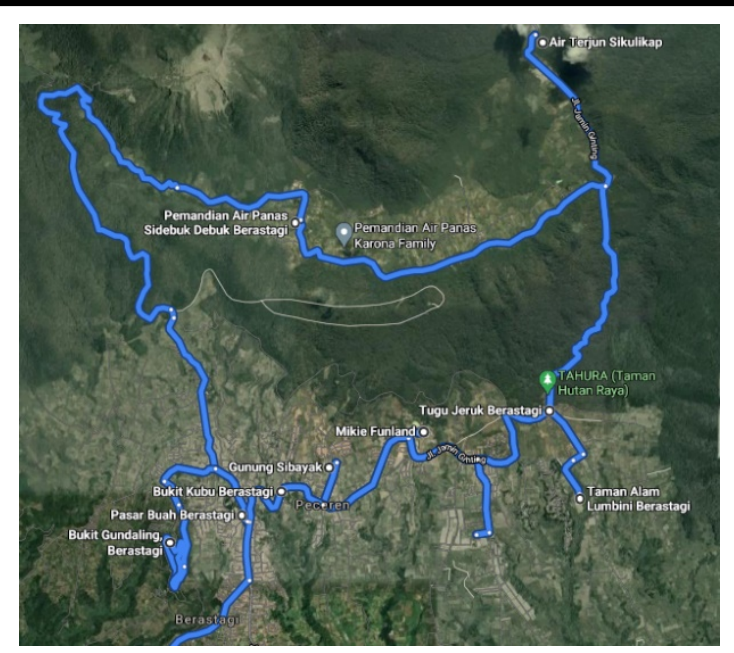

Gambar 4. 2 Rute Perjalanan Seluruh Objek Wisata di Kabupaten Karo

Secara geografis terdapat beberapa objek wisata yang menjadi tujuan wisatawan lokal dan mancanegara dengan menarik animo masyarakat yang cukup tinggi yaitu:

1. Air Terjun Sikulikap

2. Pemandian Air Panas Sidebuk debuk Berastagi

3. Gunung Sibayak

4. Bukit Kubu Berastagi

5. Pasar Buah Berastagi

6. Bukit Gundaling Berastagi

7. Mikie Funland

8. TAHURA

9. Tugu Jeruk Berastagi

10. Taman Alam Lumbini Berastagi

11. Kabanjahe

12. Gunung Sinabung

13. Danau Lau Kawar

14. Tongging

Tabel 4. 1 Hasil Akhir Perhitungan Rute Perjalanan Objek Wisata

\begin{tabular}{|c|c|c|}
\hline $\begin{array}{c}\text { Banyak } \\
\text { Kota }\end{array}$ & Jalur & Jarak dan Waktu Terpendek \\
\hline 1 & - & \\
\hline 2 & - & \\
\hline 3 & $1-2-6$ & $28,7 \mathrm{Km}, 1$ Jam 11 Menit \\
\hline 4 & $1-8-9-10$ & $19,5 \mathrm{Km}, 42$ Menit \\
\hline 5 & $1-2-5-13-12$ & $60,9 \mathrm{Km}, 2$ Jam 16 Menit \\
\hline 6 & $1-8-9-7-3-4$ & $24,2 \mathrm{Km}, 52$ Menit \\
\hline 7 & $1-8-9-7-3-2-6$ & $46,2 \mathrm{Km}, 1$ Jam 52 Menit \\
\hline 8 & $1-2-5-11-9-7-3-4$ & $71,1 \mathrm{Km}, 2$ Jam 32 Menit \\
\hline 9 & $1-8-9-7-3-2-5-13-12$ & $78,4 \mathrm{Km}, 2$ Jam 57 Menit \\
\hline 10 & $1-8-9-7-3-2-5-11-13-12$ & $100,7 \mathrm{Km}, 3$ Jam 35 Menit \\
\hline
\end{tabular}

\subsection{Shortest Path Objek Wisata Kabupaten Karo}

Berdasarkan perhitungan yang telah dilakukan akan di bentuk model perjalanan objek wisata di Kabupaten Karo dengan memperhatikan panjang jarak dan durasi perjalanan antar lokasi. 
Pasukat Sembiring, et al Counseling to the Karo Regency Tourism and Culture Office for Optimizing the Selection of Tourism Routes in Karo Regency

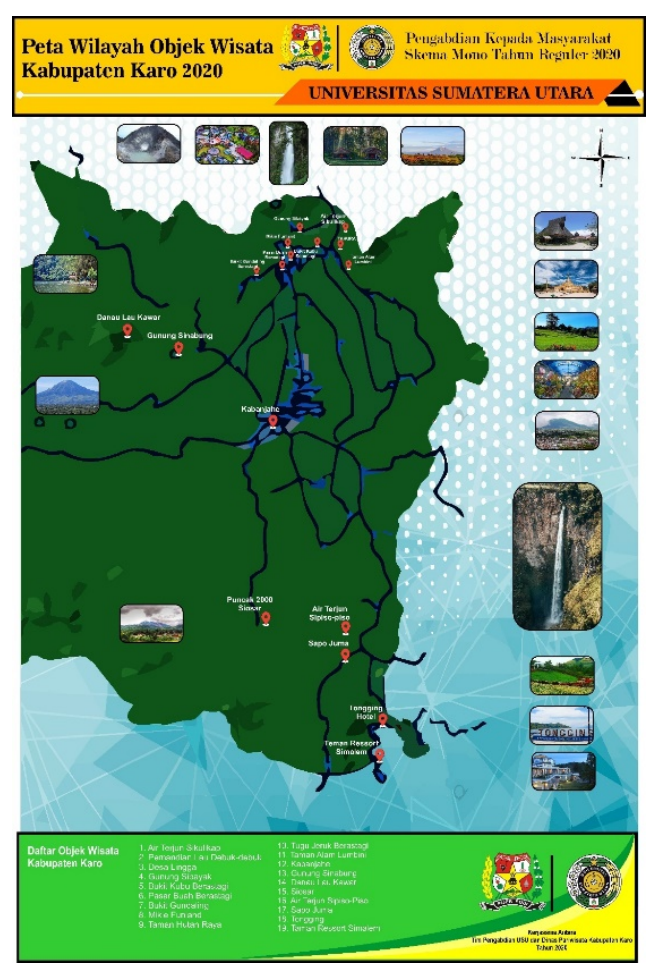

Gambar 4. 1 Peta Wilayah Perjalan Objek Wisata di Kabupaten Karo

\section{KESIMPULAN}

Berdasarkan perhitungan yang telah dilakukan dengan menggunakan metode program dinamik dan metode simple hill climbing didapatkan alternatif rute perjalanan yang dapat di jadikan refrensi dalam menjalani objek wisata di Kabupaten Karo. Rute yang telah di lakukan perhitungan berdasarkan iterasi yang telah dilakukan rute perjalanan dapat dipilih berdasarkan jarak objek wisata dan durasi perjalanan terjadi.

\section{UCAPAN TERIMAKASIH}

Terimakasih kepada Rektor USU dan LPPM USU yang telah memberikan dana pengabdian tahun 2020 Skema Profesor mengabdi.

\section{DAFTAR PUSTAKA}

Primadany, S. R. (2013). Analisis Strategi Pengembangan Pariwisata Daerah (Studi pada Dinas Kebudayaan dan Pariwisata Daerah Kabupaten Nganjuk). Jurnal Administrasi Publik, 1(4), 135-143.

Haque, M.J., dan Magld, K.W. (2012). An intelligent approach for Intrusion Detection based on data mining techniques. Multimedia Computing and Systems (ICMCS), 2012 International Conference on , vol., no., pp.12,16, 10-12 May 2012.

Retno, Margono dan Bambang Eka Purnama. ISSN 1979 - 9330. Study of Interaktif Recognition Letter and Number For Children With Computer Multimedia. Indonesian jurnal on Computer Science - Speed (IJCSS) 4 Vol. 3 Nomor 1 Agustus 2008

Script Island. 2008. Panduan Mudah Membuat Animasi. Jakarta: Media Kita.

Tulus, Sawaluddin, T.J. Marpaung, dan M.R. Syahputra. 2018. Making Learning Teaching Materials in School Based On Information And Communication Technology. Abdimas Talenta. Vol. 3 No. 2 pp. 202-2016

Widyastuti, A. R. (2010). Pengembangan pariwisata yang berorientasi pada pelestarian fungsi lingkungan. Ekosains, 2(3). 